\title{
MMADHC Gene
}

National Cancer Institute

\section{Source}

National Cancer Institute. MMADHC Gene. NCI Thesaurus. Code C74465.

This gene is involved in vitamin metabolism. 